\title{
Assessment of the reliability of fish consumption as an indicator of reef fish catches in small Pacific islands: The example of Ouvea Island in New Caledonia
}

\author{
Marc Léopold $^{1, \text { a }}$, Jocelyne Ferraris ${ }^{1}$ and Pierre Labrosse ${ }^{2,3}$ \\ Institut de Recherche pour le Développement, UR-CoRéUs, EPHE/Université de Perpignan, 66860 Perpignan Cedex, France \\ 2 Secretariat of the Pacific Community, BP D5, 98848 Nouméa Cedex, New Caledonia \\ 3 École Pratique des Hautes Études, Université de Perpignan, 66860 Perpignan Cedex, France
}

Received 10 February 2004; Accepted 24 May 2004

\begin{abstract}
Fishing pressure on reef fish stocks, in relation to exploitable biomass, is a useful parameter for fishery resource management but difficult to assess in subsistence fisheries. A methodology for indirect fishery output assessment in island environments is proposed based on estimates of consumption and the relevant seafood trade. Ouvea atoll in the South Pacific (Loyalty Islands, New Caledonia), where subsistence fishing is the main activity, was used as the experimental site. A consumer survey of the islands' households was conducted in June 2000. The sampling plan was determined on the basis of data already available on the population concerned, making it possible to give quantitative and qualitative information on catches. Total catch is estimated to be $212 \mathrm{ty}^{-1}$ composed mainly of Lethrinidae, Serranidae and Gerreidae. Subsistence activity is the main source of supply for two-thirds of households. These results were validated by a survey carried out on fishers at the same time that confirms the reliability of fish consumption as an indicator of reef fish catches. This study also showed that shoreline fishing remains the main activity in Ouvea: it's practised by $71 \%$ of households and provides almost $48 \%$ of total landings. A second stage was the identification of variables liable to influence consumption patterns: fishing practice (frequency and gear type), income, and household size seemed to be the main determining factors. These variables were integrated into a multi-dimensional analysis in order to define types of consumers. This consumption-based approach underlies a sampling strategy that could be extrapolated to other small South Pacific islands. It involves advantages of various kinds - accuracy, reliability, and cost-effective implementation - that make it a powerful tool for monitoring island fishery development.
\end{abstract}

Key words: Consumer survey / Subsistence fishery / Coral reef resources / Household / Indicator

Résumé - Évaluation de la fiabilité de la consommation de poisson comme indicateur des captures de poissons récifaux dans les petites îles du Pacifique : l'exemple de l'île d'Ouvéa en Nouvelle-Calédonie. La pression de pêche, reliée à la biomasse exploitable, est un paramètre utile pour la gestion des stocks de poissons récifaux, mais elle est difficile à évaluer pour la pêche de subsistance. Une méthodologie d'évaluation indirecte de la production halieutique est proposée, basée sur des estimations de consommation et d'échanges de produits de la mer. L'atoll d'Ouvéa dans le Pacifique sud (îles Loyauté, Nouvelle-Calédonie), où la pêche de subsistance est l'activité principale, a servi de site expérimental. Une enquête de consommation a été conduite chez les ménages de l'île en juin 2000. Le plan d'échantillonnage, défini à partir de données disponibles sur la population, a permis d'apporter des informations quantitatives et qualitatives sur les captures : la production totale, estimée à 212 t par an, se compose principalement de Lethrinidés, Serranidés et Gerréidés. La pêche de subsistance représente la principale source d'approvisionnement pour les deux tiers des foyers. Ces résultats ont été validés par une enquête conduite simultanément auprès des pêcheurs qui a confirmé la fiabilité de la consommation de poisson comme indicateur des captures de poissons récifaux. Cette étude de la production halieutique a également montré que la pêche littorale reste l'activité principale à Ouvéa : $71 \%$ des ménages la pratiquent et elle représente près de $48 \%$ des débarquements. Dans un second temps, l'étude a porté sur les variables susceptibles d'influencer la consommation de produits de la mer : la pratique de la pêche (fréquence et types d'engins utilisés), les revenus et la taille des ménages semblent être les facteurs déterminants. Ces variables ont été introduites dans une analyse multi-dimensionnelle afin de définir des types de consommateurs. Cette méthode basée sur la consommation de poisson décrit une stratégie d'échantillonnage qui pourrait être extrapolée à d'autres petites îles du Pacifique sud. Elle présente divers avantages (précision, fiabilité, facilité et rapidité de mise en œuvre) qui en font un outil performant pour suivre le développement des pêcheries insulaires.

\footnotetext{
a Corresponding author: marc_leopold@yahoo.com
} 


\section{Introduction}

The high diversity of coral reef ecosystems, combined with the many different forms of exploitation in use, makes resource management in Pacific islands a very complex matter. Subsistence fishing is the main factor in the exploitation of coastal marine resources, however there is little accurate and verifiable data about yields and landings (Dalzell et al. 1996). Coral reef ecosystems provide important food sources for many countries and the coastal fisheries play an extremely important role for the food security of small islands in the Pacific (MacManus 1997; Watson and Pauly 2001). The demographic development of these islands and their transformation from subsistence to market societies increase the risk of overexploitation of the coastal resources. Sustainable management of coral reef ecosystems requires better knowledge of the impact of the subsistence fisheries and its impacts on reef and lagoon biodiversity.

In this regard, an analysis of seafood consumption can be a good alternative as an indirect assessment of fishery production (Loubens 1975; Paddon 1997; Labrosse and Letourneur 1998; Labrosse et al. 2002; Labrosse 2003). Each island can be considered as a well-limited system with some reef fishes being imported or exported. The level of exploitation of the fishery basically depends on its biological productivity, determined by the size and type of the island (high island with or without a lagoon, atoll), the density of the surrounding population, the fishing gears used, and food and cultural habits. Then, catches are proportional to the level of local consumption extended to the more general case of an island trading with the outside world:

Fishery Production of Island $\left(P_{\mathrm{T}}\right)=$ Island Subsistence Consumption $\left(C_{\mathrm{T}}\right)+\operatorname{Exports}\left(E_{\mathrm{T}}\right)-$ Imports balance.

In most Pacific Island countries and territories subsistence fishery catch data are deduced empirically from national consumption studies which are not designed specifically for this purpose (Dalzell et al. 1996). They may also come from catch assessment surveys with fishers (Aubanel 1993; Labrosse et al. 2000). These methods provide either crude estimates without any detail about the type and the origin of the seafood or partial estimates taking no account the heterogeneity of the island fishery. A more holistic approach is necessary for fishery management (Botsford et al. 1997), and indicators are required to better understand the influences of fisheries on the ecosystem (Garcia and Staples 2000). This article proposes to validate a fish consumption study method appropriate for an island setting providing qualitative and quantitative indicators on subsistence catches (total catches, diversity, and relative importance of target species). It is based on community surveys using a sampling protocol developed in a small island of the South Pacific: the atoll of Ouvea in New Caledonia (Fig. 1). In order to show fish consumption as a reliable indicator of the fish production, two simultaneously surveys were undertaken: one on consumers and the other on fishers. Relevant, quick, and precise information about the fish production is required to define a good indicator (Dale et al. 2001; Kurtz et al. 2001). So, the results of this analysis were interpreted in terms of the validity and potential of this methodology. The limits of use of the "consumption" parameter as a fishery production and resource exploitation-monitoring indicator are also discussed.
At the regional scale, this methodology could be transposable to other islands where food security depends to a great extent on coastal resources.

\section{Material and methods}

\subsection{Study area}

Ouvea is an atoll located in the Loyalty Islands about $100 \mathrm{~km}$ East from the main island of New Caledonia (Fig. 1). In 1991-1992, Ouvea was the subject of a study on the structure of reef and lagoon communities, which stressed the diversity of the "macrovertebrate" populations, subject to low fishing pressure (Kulbicki et al. 1994; Kulbicki 1995). Over the 20 villages of the island, Melanasian represents more than $97 \%$ of the total population (ITSEE 1997, 1998) still keeping a traditional lifestyle. Within this community traditional rules and informal obligations play a leading role in the relations between people and between them and their environment (Leblic 1993). They give major importance to non-monetary exchanges, in which fish is often involved (ITSEE 1993b,d). Fishing rights, as evidence of ancestral sharing of activities and functions between clans, remain unequal between households (Leblic 1993).

\subsection{Observation unit}

The "demographic household" was adopted as the observation unit: it is defined as the usual occupants (whatever the ties between them are) of a private dwelling unit (separate and independent accommodation) used as a main place of residence (INSEE-ITSEE 1997). Its members are usually related in kinship to other inhabitants and recognize the authority of the same person, referred to as the "head of household"; it includes traditionally adopted children. All members eat most of their meals together. This last criterion was decisive in the choice of the observation unit.

\subsection{Sampling procedure}

The statistical population comprises 728 households (INSEE-ITSEE 1997). The 1996 New Caledonia population census provided specific information on Ouvea's households: distribution by tribu (village), size structure, fishing activity (whether income-generating or not), and socio-occupational category (SOC) of the head of household (ITSEE). Additional data on measured variables are often a factor in improving the accuracy of estimators when used at the sampling unit definition stage (Ardilly 1994). The data for each household were thus used as the basis for a double stratification of the sample:

1) primary stratification: the extent of fish sales within a tribu could be a way of measuring the scale of fishing activity. It should have an influence on the consumption of all the individual members of a tribu because of the high frequency of fish gifts. On the basis of this assumption, the tribus were divided into two classes of equal size: in class 1 , over $15 \%$ of 


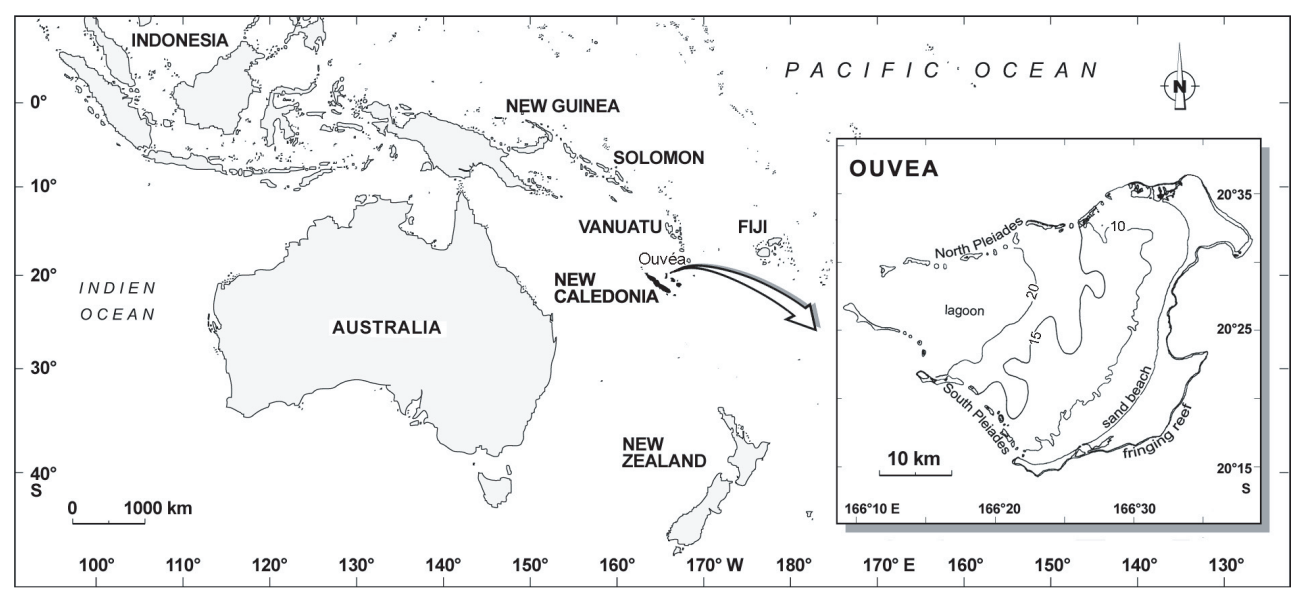

Fig. 1. Morphology of Ouvea atoll (South Pacific). The east coast, exposed to the trade winds, has a fringing reef; a white sand beach lies along the western lagoon edge. The lagoon extends over an area of $872 \mathrm{~km}^{2}$, with an average depth of $15 \mathrm{~m}$. A series of islets and reefs mark its northern and southern edges.

households sell part of their catch, while under $15 \%$ do so in class 2 (ITSEE).

2) secondary stratification: in New Caledonia, average household fish consumption varies greatly depending on the SOC of the head of household (ITSEE 1993a). On this assumption, a stratification of the SOC into three classes of consumer was performed: SOC1 = Farmers and equivalents, artisans, shopkeppers, workers, wage-earners, old-age pensioners; SOC2 = Managerial staff and equivalents, intermediate occupations; SOC3 = Unemployed workers, people with no financial income.

The level of consumption of households is related to their size (ITSEE 1993a). Because of the small size of the final sample and the variability of this criterion on Ouvea (ITSEE), this variable was not introduced into the stratification plan.

The distribution of the statistical population of households within the six strata resulting of the double stratification is shown in Table 1. In view of the duration of the survey (two months) undertaken by one recorder, the size of the sample was set at 30 households, corresponding to $4.1 \%$ of the population. In regards to the sampling effort to be allocated per stratum, the consumption of a stratum was estimated as the product of number of households per stratum multiplied by average consumption per household (Table 1). The distribution of the sample within the primary and secondary strata was done proportionately to this theoretical total consumption figure (Table 2). Sampling was therefore representative of the variable studied and not of the relative number of statistical units of each stratum (Grosbras 1987).

The sampling unit arose from the random selection of 30 tribus/SOC class pairs. The names of sample members were not accessible and the 30 households meeting this dual criterion were determined in the field on a voluntary basis.

\subsection{Data collection}

Between May and June 2000, surveys were conducted with the selected households. For each household, the questionnaires included individuals' ages and household size, the occupation of the head of household, the frequency of consumption of fish in number of meals per week, the quantity of fish prepared per meal, the species consumed (order of priority and seasonality, if any) and the origin of the fish consumed. From individuals' ages household size was expressed in consumption units (CU). This unit makes it possible to take into consideration the age structure; it is defined by the Oxford Scale (ITSEE 1993c). On Ouvea 2702 CU were recorded in 1996 (ITSEE). The possible fishing activity within sampled households has been briefly described (gear available, frequency of activity, use of catches) for the purpose of facilitating data processing and analysis of the relationship between consumption and production.

\subsection{Supplementary surveys}

There was no recent, comprehensive and reliable statistical information available on fishing on Ouvea or its fish trade. This information was specifically sought and compared with the results of the analysis of consumption. A sample of fishing households was surveyed. The productivity differences between the various gear types produced a distinction between two production methods: fishing from motorised craft (or coastal fishing using drop-lines) assumed to be more efficient and fishing on foot and from rowing boats (or shoreline fishing, gears include hand-lines, drive-in nets, scoop nets and spears). Total production was considered to be the sum of coastal and shoreline production combined. The nature of catches is also analysed.

Motorised craft were counted by direct observation. Sixtyfive households owned this means of production: 23 "fulltime" units $=N_{1}$ (at least 52 trips per year) and 42 "parttime" units $=N_{2}$ (less than 52 trips per year). Because of the small size of the target population, judgement sampling was performed in order to improve the accuracy of the production estimate. The most active fishers were surveyed comprehensively and the least active vessels by a random method and a minimum sampling percentage of $10 \%$. 
Table 1. Household fish consumption according to socio-occupational categories (SOC). Distribution of Ouvea households within the six sampling strata (from ITSEE 1993a). 1 euro = 119.3 F CFP.

\begin{tabular}{|l|c|c|c|c|}
\cline { 3 - 5 } \multicolumn{1}{c|}{} & \multirow{2}{c}{$\begin{array}{c}\text { Household consumption } \\
\text { (thousands F CFP) }\end{array}$} & \multicolumn{3}{c|}{ Number of households } \\
\cline { 3 - 5 } \multicolumn{1}{c|}{} & & $\begin{array}{c}\text { Ouvea } \\
\text { population }\end{array}$ & $\begin{array}{c}\text { Class 1: villages } \\
\text { with high trade }\end{array}$ & $\begin{array}{c}\text { Class 2: villages } \\
\text { with low trade }\end{array}$ \\
\hline $\begin{array}{l}\text { SOC 1: Farmers and equivalents, } \\
\text { artisans, shopkeppers, workers, wage- } \\
\text { earners, old-age pensioners }\end{array}$ & 203.6 & 343 & 190 & 153 \\
\hline $\begin{array}{l}\text { SOC 2 : Managerial staff and } \\
\text { equivalents, intermediate occupations }\end{array}$ & 122.8 & 56 & 20 & 36 \\
\hline $\begin{array}{l}\text { SOC 3: Unemployed workers, people } \\
\text { with no financial income }\end{array}$ & 55.8 & 329 & 89 & 240 \\
\hline
\end{tabular}

Table 2. Distribution of sampling units within the six strata, proportionately to the average consumption per stratum. (SOC 1: Farmers and equivalents, artisans, shopkeppers, workers, wage-earners, old-age pensioners; SOC 2: Managerial staff and equivalents, intermediate occupations; SOC 3: Unemployed workers, people with no financial income).

\begin{tabular}{|c|c|c|c|c|c|}
\hline & \multicolumn{2}{|c|}{ Villages of class 1} & \multicolumn{2}{|c|}{ Villages of class 2} & \multirow{2}{*}{$\begin{array}{c}\text { Total of } \\
\text { Secondary strata }\end{array}$} \\
\hline & $\begin{array}{c}\% \text { of Ouvea total } \\
\text { consumption }\end{array}$ & $\begin{array}{l}\text { Sample } \\
\text { number }\end{array}$ & $\begin{array}{c}\% \text { of Ouvea total } \\
\text { consumption }\end{array}$ & $\begin{array}{l}\text { Sample number } \\
\text { number }\end{array}$ & \\
\hline SOC 1 households & 40.3 & 12 & 33.2 & 10 & 22 \\
\hline SOC 2 households & 2.6 & 1 & 4.6 & 1 & 2 \\
\hline SOC 3 households & 5.3 & 2 & 14.0 & 4 & 6 \\
\hline Total of Primary strata & 48.2 & 15 & 51.8 & 15 & 30 \\
\hline
\end{tabular}

The number of households comprising shoreline fishers $\left(N_{3}=520\right)$ was extrapolated from the proportion of this category of household in the consumer survey sample, with an adjustment factor of the relative weight of households. At the same time, these households described their possible shoreline fishing activity, as did households owning a motorised craft. Lastly, in order to complete the sample so as to cover the full range of gear types and fishing grounds, other shoreline fishing households were surveyed at random along the coast. A comprehensive survey of traders, the hospitality sector and fishers concerned made it possible to carry out a direct estimate of fish imports and exports.

\subsection{Statistical processing}

The list of the symbols used for data processing and their description are given in Table 3. The mathematical expressions used to estimate consumption and fish production are as follows:

- Annual consumption per household: $C_{\bullet}=52 \times C_{r, i} \times F_{r, i}$. where $F_{r, i}$ is the frequency of consumption of fish in number of meals per week and $C_{r, i}$, is the quantity of fish prepared per meal for the household $i$.

- Annual catch per household $i\left(P_{\bullet_{i}}\right)$ were estimated by the formula $P_{\bullet i}=\sum_{g}\left(P_{g, i} \times F_{g, i}\right) \times 52$, where $P_{g, i}$ is the mean catch per trip with gear type $g$ and $F_{g, i}$ is the mean number of trips per week with gear type $g$.

- Production of most active fishers $\hat{P}_{1}=\sum_{j=1}^{23} \hat{P}_{1 j}$.

- Production of the least active vessels $\hat{P}_{2}=\bar{p}_{2} \times N_{2}$ where $\bar{p}_{2}$ is the mean annual production for this type of craft and $\mathrm{N}_{2}$ the number of fishers.
- Production of the shoreline fishing activity (noted $P_{3}$ ) is therefore equal to $\hat{P}_{3}=\bar{p}_{3} \times N_{3}$ where $\bar{p}_{3}$ is mean annual production by this category of fisher and $N_{3}$ the number of fishers.

The consumption for the island $\left(C_{\mathrm{T}}\right)$ was estimated from the consumption per CU. It is equal to the product of the island population in consumption units multiplied by mean annual consumption per $\mathrm{CU}$, noted as $\Lambda . \hat{\Lambda}$, division or quotient random variable, is expressed by $\bar{c} / \bar{u}$, with $\bar{c}$ mean annual consumption per household per year, and $\bar{u}$ mean household size in CU in the sample.

Fish production $\left(P_{\mathrm{T}}\right)$ was estimated by the sum of the three components $\hat{P}_{\mathrm{T}}=\hat{P}_{1}+\hat{P}_{2}+\hat{P}_{3}$. The associated estimation uncertainties were calculated (Cochran 1963).

The data collected on consumption were subjected to multiple correspondence factorial analysis (MCFA), in order to establish the structuring factors of the consumption variable per CU. The MCFA is performed using the SPAD.N software (Lebart et al. 1987), incorporating all the randomly selected households; the other households were introduced as illustrative observations. A cluster-type or "ascending hierarchical" classification was performed on the factorial co-ordinates, taking into account total variability so as to create partitions by minimisation of within-class variance (Ward 1963); the partition was described in order to understand the structure of the households of Ouvea with the point of view of their fishing activity and fish consumption.

Owing to the very high variability of household consumption levels within the strata defined in the sampling plan, the stratification plan was questioned. An adjustment of sampling weights was applied to individuals in order to restore the conditions for a simple random sampling without replacement. $W_{i}$ is the adjustment factor for the relative weight of the item, the household $i(i \in[1, n])$ (Ardilly 1994): $W_{i}(k, h)=N_{k, h} /\left(N n_{k, h}\right)$, 
Table 3. List of symbols and definitions.

\begin{tabular}{|l|l|l|}
\hline Symbol & Definition & Categories ou unit \\
\hline & & $\begin{array}{l}\text { SOC 1 = Farmers and equivalents, artisans, shopkeppers, workers, wage- } \\
\text { earners, old-age pensioners; SOC 2 = Managerial staff and equivalents, } \\
\text { intermediate occupations; SOC 3 = Unemployed workers, people with no } \\
\text { financial income. }\end{array}$ \\
\hline CU & Socio-occupational category & $\begin{array}{l}\text { Defined by Oxford Scale (head of household = 1; other people older than } \\
14=0.7 ; \text { children }=0.5) .\end{array}$ \\
\hline$\hat{\Lambda}$ & Fish consumption per CU within a household & $\mathrm{kg} \mathrm{y}^{-1}$ \\
\hline$C_{\mathrm{T}}$ & Ouvea annual fish consumption & $\mathrm{t} \mathrm{y}^{-1}$ \\
\hline$P_{1}$ & Fulltime vessels fish production & $\mathrm{t} \mathrm{y}^{-1}$ \\
\hline$P_{2}$ & Part-time vessels fish production & $\mathrm{t} \mathrm{y}^{-1}$ \\
\hline$P_{3}$ & Shoreline fish production & $\mathrm{t} \mathrm{y}^{-1}$ \\
\hline$P_{\mathrm{T}}$ & Ouvea annual fish production & $\mathrm{t} \mathrm{y}^{-1}$ \\
\hline$E_{\mathrm{T}}$ & Ouvea annual fish exports & $\mathrm{t} \mathrm{y}^{-1}$ \\
\hline
\end{tabular}

with $N$ and $n$ being population and sample numbers respectively, and $k, h$ index of the village and SOC strata referred to above. Eight supplementary households were randomly surveyed during field operations in order to complete the sampling process. The final sample is therefore composed of $n=$ 38 households.

In other respects, the statistical conditions of the probability-based calculations were not always fully complied with. Annual consumption per household and annual catch per household are composite variables whose estimates of mean and variance are complex to define strictly (Cochran 1963); they were considered on an approximate basis as a simple variables. Samples of motorised boat fishers and shoreline fishers were not independent, even considered so in fish production estimation $\left(P_{\mathrm{T}}\right)$ : a few surveyed households include both types. Lastly, part-time vessels sample is composed of only 19 units: catches probability law of this strata $\left(P_{2}\right)$ and its variance components must be treated with caution.

\section{Results}

\subsection{Assessment of the island's consumption}

Each household consumes an average of $289 \mathrm{~kg}$ of fish per year, with a dispersal of $281 \mathrm{~kg}$. The mean size of a household is $4.4 \mathrm{CU}$ and the standard deviation 1.5 CU. Mean fish consumption per $\mathrm{CU}$ is $63 \mathrm{~kg} \mathrm{y}^{-1}$. Variance within the sample and the standard deviation in estimating $\hat{\Lambda}$ are respectively $51.2 \mathrm{~kg} \mathrm{y}^{-1}$ and $9.7 \mathrm{~kg} \mathrm{y}^{-1}$. The island's total consumption from the 1996 census was approximately $170 \mathrm{ty}^{-1}$, with a standard deviation for the estimation of some $27 \mathrm{t}$. By normal approximation from the law of $\Lambda$, the confidence interval $\hat{C}_{\mathrm{T}}$ at a $95 \%$ probability is $[118 \mathrm{t} ; 222 \mathrm{t}]$. By including the mean annual demographic growth of $1.7 \%$ observed on Ouvea over the 1989-1996 period (INSEE-ITSEE 1997), total consumption is estimated for 2000 at $182 \mathrm{t}$ [126 t; $238 \mathrm{t}]$.

Consumption is highly diversified: 51 reef and lagoon species are consumed on a reasonably regular basis. Some

\section{ĐSpecies $n^{\circ} 1 \quad \square$ Species $n^{\circ} 2 \quad \square$ Species $n^{\circ} 3$}

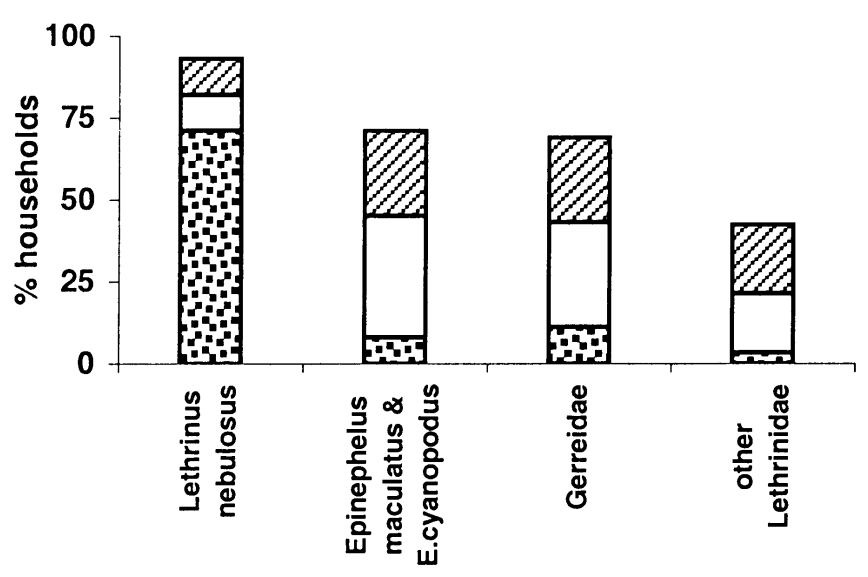

Fig. 2. Main species consumed in Ouvea households in order of importance and on an annual basis. The 1, 2, 3 order reflects main, secondary and tertiary consumed species respectively, on a relative scale (no estimate of consumption per species available).

of them are more frequently targeted than others: in decreasing order of popularity, we find Lethrinidae Lethrinus nebulosus (94\% of households), Serranidae Epinephelus cyanopodus and Epinephelus maculatus (77\%), Gerreidae Gerres oyena (74\%), other Lethrinidae (42\%) and less frequently Siganidae (1 household in 6). The consumption of certain species increases clearly at a specific time of year: Scombridae Rastrelliger kanagurta (June to December, peak in July-August), Gerres oyena (January-February), Engraulidae Thryssa baelema (July-August), Siganidae Siganus sp. (from May-June), Mullidae Upeneus vittatus (June) and some Mugilidae (June to August). The most important species in the consumption patterns of the people of Ouvea are: Lethrinus nebulosus firstly and secondly Epinephelus maculatus, Epinephelus cyanopodus and Gerres oyena (Fig. 2). 


\section{घOrigine $n^{\circ} 1 \quad \square$ Origine $n^{\circ} 2 \quad$ OOrigine $n^{\circ} 3$}

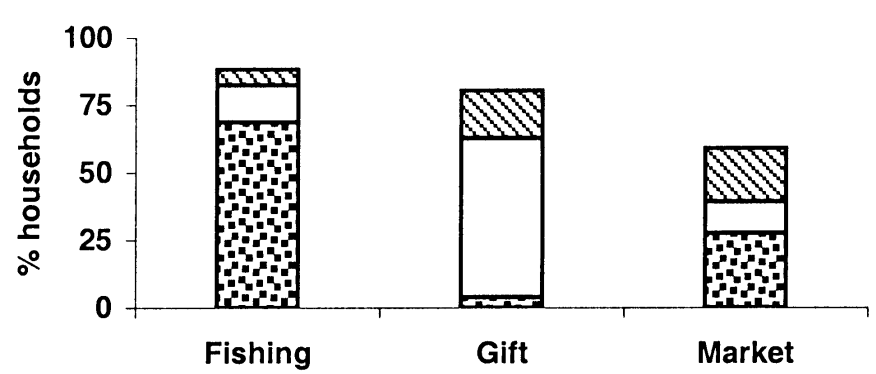

Fig. 3. Origin of fish consumed by Ouvea households. Three sources of supply are referred to. The 1, 2, 3 order reflects main, secondary and tertiary origins respectively, on a relative scale (no estimate of supply per origin available).

Subsistence production is the main source of supply for two-thirds of households surveyed and almost nine households out of ten fish on a reasonably regular basis. Fifty-nine percent report that they purchase fish in nearby stores, with $45 \%$ saying that this is their preference, before giving away fish or catching it themselves. Gifts in kind often represent the second source of supply (Fig. 3).

\subsection{Assessment of the island's fish catches}

Annual production $P_{1}$ of 23 active fishing craft (100\% of $N_{1}$ ) is estimated at $69.5 \mathrm{t}$ or an average of $3.0 \mathrm{t}$ per craft; standard deviation is $1.9 \mathrm{t}$.

Twenty relatively inactive craft were also surveyed (46.7\% of $N_{2}$ ). One household conducts seasonal purse-seine fishing, with very high productivity: annual landings are $7.8 \mathrm{t}$ despite a limited number of trips. Apart from this special case, mean individual production for these less active craft is $960 \mathrm{~kg} \mathrm{y}^{-1}$ with a standard deviation of $380 \mathrm{~kg}$. Total production for this group of 42 craft is $47.2 \mathrm{ty}^{-1}$. If it is considered that the mean $\bar{p}_{2}$ approximately follows the Student law at 18 degrees of freedom (excepting the atypical craft), the $95 \%$ confidence interval are between 41.6 and $52.8 \mathrm{t}$. The total production of households owning a motorised craft is therefore estimated at $117 \mathrm{ty}^{-1}$, with an uncertainty of the order of $\pm 5,6 \mathrm{t}$. About $42 \%$ of this tonnage goes to market, $79 \%$ (33 t) locally.

Forty-three households involved in shoreline fishing were surveyed $\left(8.3 \%\right.$ of $\left.N_{3}\right)$. Unitary annual catches were highly varied ranging from 4.5 to $1200 \mathrm{~kg} \mathrm{y}^{-1}$. For this reason, the average was calculated from $75 \%$ of units sampled after truncating off the ten end values: it amounted to $202 \mathrm{~kg} \mathrm{y}^{-1}$ with a standard deviation of $136 \mathrm{~kg}$. Seventy-one percent of Ouvea households fish along the water's edge, with varying frequencies. Shore fishing produces 105 t of catches per year, $2.5 \%$ of which is marketed (on Ouvea only). The standard deviation in estimating $\hat{P}_{3}$ is approximately $10 \mathrm{t}$.

Total annual fish production could therefore be estimated at $222 \pm 26 \mathrm{t}$.

No time effect was observed on reported catches, as reported over a one-year period. Fifty-one target species were surveyed. The occurrence of some species in catches showed seasonal variation: this mostly applies to Rastrelliger
ESpecies $n^{\circ} 1 \quad \square$ Species $n^{\circ} 2 \quad \square$ Species $n^{\circ} 3$

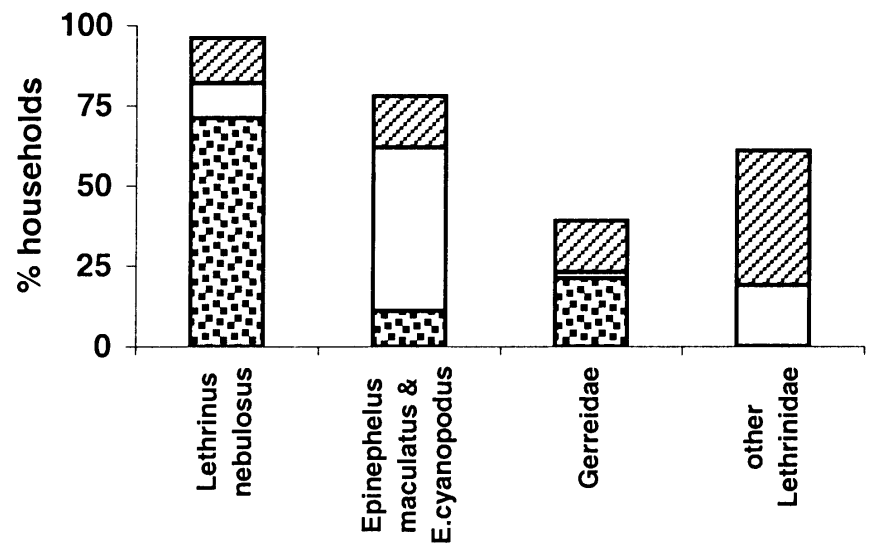

Fig. 4. Main species of fish targeted by Ouvea households, in order of importance and on an annual basis. The 1,2,3 order reflects main, secondary and tertiary targeted species respectively, on a relative scale (no estimate of landings per species available).

kanagurta, Thryssa baelama, Gerres oyena, Siganus sp., and Upeneus vittatus. Lethrinus nebulosus is subjected to the greatest annual fishing pressure. Epinephelus maculatus, Epinephelus cyanopodus and Gerres oyena represent target species of secondary importance. Other Lethrinideae are also extensively targeted (Fig. 4).

\subsection{Estimates of the fish trade}

No fresh or frozen fish imports were recorded on Ouvea during the survey period. It emerged however that some hotels and restaurants did import fish when local supply was insufficient; the quantities imported amounted to a few hundred kilograms and were left out of the analysis. Exports are often informal in nature and therefore difficult to assess. They probably amount to $30-35 \mathrm{ty}^{-1}$ and can be broken down as follows: 1) direct sale off-island: $11.5 \mathrm{ty}^{-1}$; 2) sale to hotels and restaurants: $1.5 \mathrm{ty}^{-1}, 3$ ) in-kind gifts of fish purchased on Ouvea and sent overseas: $18 \mathrm{ty}^{-1}$ and 4) in-kind gifts of fish from subsistence activity sent overseas: several tons per year.

\subsection{Exploratory data analysis}

The MCFA is performed incorporating height nominal variables (Table 4) and 38 randomly selected households. Twelve other households involved in fishing were surveyed and introduced as illustrative observations. Continuous variables are coded in modalities according to their distribution in the households sample. The first two values specific to the MCFA explain $41.6 \%$ of the initial inertia (Fig. 5). Axis I ( $21.2 \%$ of total variance) is correlated to a fishing frequency gradient. The higher-income household category (SOC 2), fishing from motorised craft, high consumption per CU and, to a lesser degree, the large size of households also contributed to the formation of Factor I (negative part of the axis). The positive part of axis I was correlated to fishing along the coastline 
Table 4. Variables incorporated in the MCFA. (CSP 1: farmers and equivalents, workers, wage-earners, old-age pensioners; CSP 2: managerial staff and equivalents, intermediate occupations, artisans, shopkeppers; CSP 3: unemployed workers, people with no financial income).

\begin{tabular}{|l|l|l|l|}
\hline \multicolumn{2}{|c|}{ NOMINAL VARIABLES } & \multicolumn{2}{|l|}{ MODALITIES } \\
\hline 1 & Household size (CU) & 3 & $<4 ; 4$ to $5 ;>5$ \\
\hline 2 & Socio-occupational category (SOC) & 3 & CSP 1; CSP 2; CSP 3 \\
\hline 3 & Household fish consumption (kg per year) (illustrative) & 4 & $<100 ; 100$ to 250; 251 to 450; $>450$ \\
\hline 4 & Fish consumption per CU (kg per year) & 2 & 1 to $65 ; 66$ to 200 \\
\hline 5 & Main origine of fish consumed (illustrative) & 2 & Market (monetary supply); Gift or fishing (non-monetary supply) \\
\hline 6 & Means of production (fishing gear) & 3 & None; Motorised craft; No motorized craft: shoreline fishing \\
\hline 7 & Fishing frequency (number of trips per month) & 4 & $0 ; 1$ to 3; 4 to 7; 8 to 10 \\
\hline 8 & Main destination of fish production (illustrative) & 2 & No production; market; Gift or own consumption \\
\hline
\end{tabular}

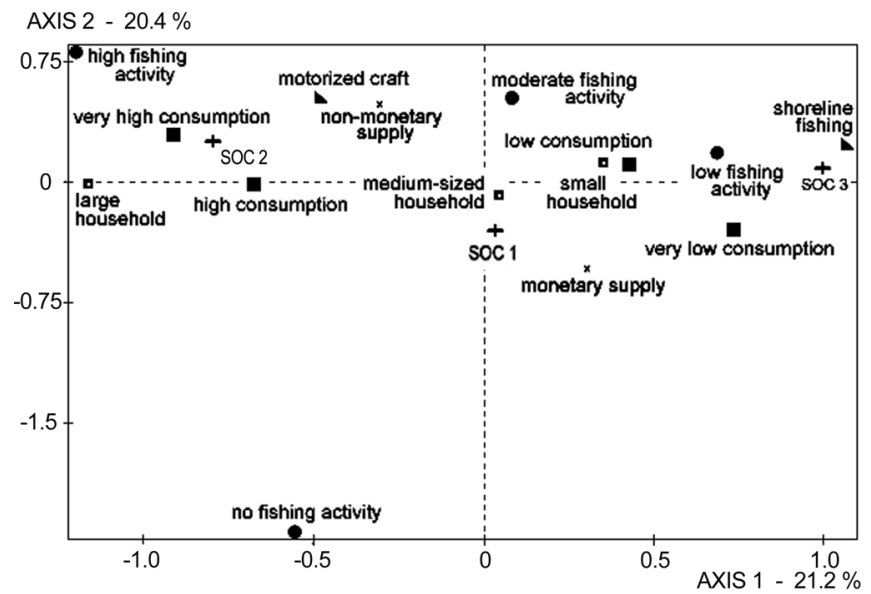

Fig. 5. Projection of the variables showing significant correlation in the two first factorial axes of the multiple correspondence factorial analysis (MCFA).

and to the unemployed category (SOC 3). Whether or not a household is involved in fishing had a strong effect on axis II (20.4\% of total variance). Projecting the additional modalities onto the main factorial axes clearly showed a consumption gradient by household on factor I. It also revealed a weak correlation with the monetary origin of consumed products in the negative part of axis II, while this axis' positive section is linked to a non-monetary origin.

The partition into three groups resulting from classification explains $35.3 \%$ of the total inertia. The tree's first dichotomy separates out the few households where nobody fishes (class 3); the origin of the fish they consume is most often monetary. The other two classes distinguished themselves by the modalities of the following variables: 1) occasional and/or shoreline fishing; low to medium monetary income (SOC 1 and SOC 3); low household and CU consumption (class 1); 2) very frequent fishing and/or fishing from a motorised craft; high monetary income (SOC 2); strong CU consumption category (class 2 ). When the subjects were projected onto the main factorial plane, classes 1 and 2 emerged on the basis of consumption gradients and fishing frequency on factor I, and class 3 set itself apart on factor II (Fig. 6). Additional items, which consist of households involved in fishing, also spread over axis I.

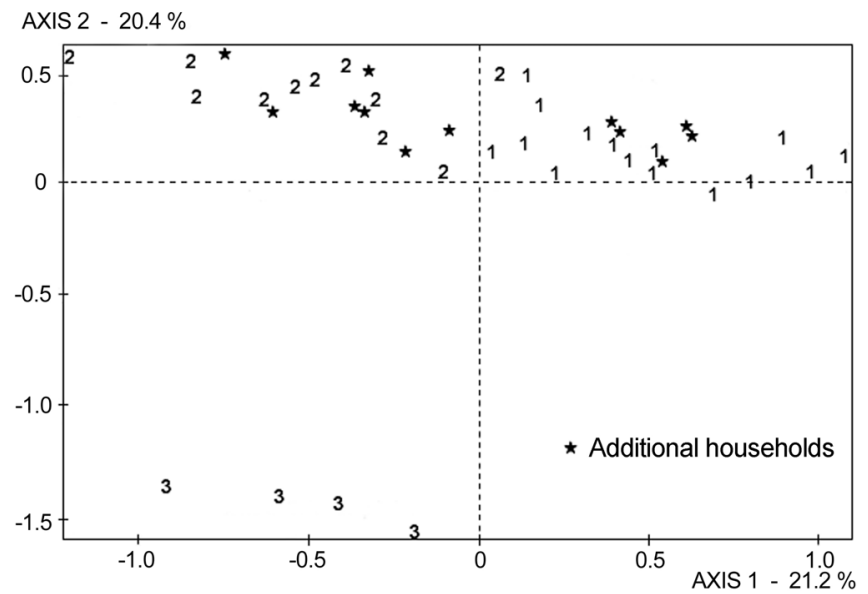

Fig. 6. Projection of active and additional households in the main plane of the MCFA after classification. The performed classification put 19 households together within class 1,13 within class 2 and 6 within class 3 .

\section{Discussion}

On the basis of the equation that fishery production of the island ecosystem $\left(P_{\mathrm{T}}\right)$ is equal to island subsistence consumption $\left(C_{\mathrm{T}}\right)$ plus the exports $\left(E_{\mathrm{T}}\right)$ (imports being insignificant in Ouvea), it is possible to calculate an error of prediction of the fishing production on the basis of the consumption of catches (inside and outside of the island) (Table 5). Fisheries production prediction error was $4.5 \%$, which demonstrates the coherence of the approach taken to fish consumption. For that reason, consumption can be considered a reliable and accurate indicator of catch level (apart from exports). From the qualitative standpoint, consumed species and target species show a great deal of similarity. The origin of fish consumed also provides reliable indications about the purpose of fishing activities.

As in many South Pacific islands, Ouvea fisheries have traditionally been focused on subsistence shoreline activity, which involves $71 \%$ of the households. Fulltime and parttime vessels provide only $52 \%$ of the seafood production and commercial landings represent no more than $6 \%$ of total catches. The methodology developed in this experimental site could therefore be transposable to other islands where reef 
Table 5. Comparison of fish population, consumption and export estimates on Ouvea. Summary of quantitative results of the various surveys.

\begin{tabular}{|c|c|c|c|c|}
\hline \multirow{4}{*}{ Fisheries production $\left(P_{\mathrm{T}}\right)$} & \multicolumn{2}{|c|}{ Estimated quantities $\left(\mathrm{t}^{-1}\right)$} & \multicolumn{2}{|c|}{ Approximate estimate of uncertainty $\left(\mathrm{t}^{-1}\right)$} \\
\hline & fulltime vessels: 69.5 & \multirow{3}{*}{ Total: 222} & fulltime vessels: 0 & \multirow{3}{*}{ Total: 26} \\
\hline & part-time vessels: 47.2 & & part-time vessels: 5.6 & \\
\hline & shoreline fishing: 105 & & shoreline fishing: 20 & \\
\hline Fish consumption $\left(C_{\mathrm{T}}\right)$ & \multicolumn{2}{|c|}{182} & \multicolumn{2}{|c|}{56} \\
\hline Fish exports $\left(E_{\mathrm{T}}\right)$ & \multicolumn{2}{|c|}{30} & \multicolumn{2}{|c|}{5} \\
\hline Error of prediction & \multicolumn{2}{|c|}{10} & & \\
\hline
\end{tabular}

Error of prediction: $\varepsilon=\frac{\delta}{\hat{P}_{\mathrm{T}}}$ where $\delta=\hat{P}_{\mathrm{T}}-\hat{C}_{\mathrm{T}}-\hat{E}_{\mathrm{T}}$

fish resources supply the population with a large portion of her diet. In the context of subsistence fishing, study of fish consumption or production is, then, of comparable interest with regard to target species (e.g. quantity, diversity, relative importance, use). Consumption can, therefore, be directly used to monitor fishing strategies and resource fluctuations as changes in the relative importance of seafood or of certain species in average eating habits can be a signal of a change in the status of the resource. On the other hand, the relative stability of eating habits over the short- and medium-terms makes that parameter more practical to implement than direct production estimator: relevant and cost-effective consumption surveys can be conducted during short periods, mainly when the variability, the complexity and the diffuse artisanal nature of coastal fisheries make difficult landings assessments (Dalzell et al. 1996). It also makes possible to analyze the progression of stock exploitation and demographic growth concurrently, apart from fish exports (Paddon 1997). In addition, consumption surveys lose their effectiveness if the incoming and outgoing amounts of fish are relatively high and poorly assessed. For that reason, it's important to monitor these movements at key locations, e.g. airports, port.

The statistical multivariate analysis allowed to provide a partial explanation of household consumption levels; they are higher when fishing occurs on a regular basis, or in the presence of high-performance fishing gear, high family income and/or large-size households. However, these four factors do not play exactly the same roles in every case and none seems to be discriminatory. In particular, the correlation between the fishing activity and consumption variables tends to prove that often what is involved is home consumption, but this relationship is not strict (Fig. 5). The effects of these variables can interact and lead to consumption levels that vary widely from the mean.

The differences observed demonstrate how difficult it is to explain variability in eating habits from a statistical point of view, especially as the social and cultural characteristics of the Melanesian community are sometimes difficult to take into account. The SOC socio-economic criterion is a good example: poorly adapted to a situation where many heads of households have several different types of employment, it also has problems taking into account overall household resources, which include the financial income of other family members and inkind gifts.

This simple random sampling-based consumption survey resulted in reliable indications of fishing activities. However, it appeared to be only half as accurate as direct assessment of production: the estimate of the island's consumption included a relatively high level of uncertainty, i.e. about $30 \%$, due to wide variations in eating habits among households and the low sample size in same strata. It was probably even higher due to potential measurement errors. In fact, it was not possible to directly measure the quantities of fish consumed at each meal: estimates were based on interviewed people assessments. The accuracy of this type of assessment had already been put into doubt during earlier studies using the quota method conducted in the Northern Province of New Caledonia (Labrosse and Letourneur 1998; Labrosse et al. 2000; Labrosse 2003): as the aim is to assess the amount of fish eaten per meal, the portion consumed per person can be difficult to estimate. Nevertheless, household-scale information may offer better stability over time and makes it easier to assess quantities consumed, producing less uncertainty. On the other hand, this type of sampling allows to give a qualitative description of seafood consumption.

A more detailed definition of the sampling plan could probably improve accuracy, while maintaining flexibility and quick implementation. The multivariate analysis gave some preliminary results: it showed that consumption can be partly interpreted by an overall approach integrating several combined explanatory variables. For that reason, the household categories defined by the cluster method showed different mean consumption levels, which were fairly homogenous. From there, identification of discriminate parameters could determine pertinent stratification criteria for improving estimator quality.

It should also be noted that the consumer and fisher household samples were not independent due to survey-related constraints: 12 households owning motorized boats and 23 households engaged in coastal fishing were included in the consumption survey. This link may have brought about bias in interpretation.

Acknowledgements. This study was conducted as part of the New Caledonia worksite of the French National Coastal Environment Program (PNEC). It benefited from the support of the Loyalty Islands Province and collaboration between the IRD and SPC on reef resources and their uses in the Pacific Islands. We would like to acknowledge the collaboration of André Page from ITSEE and Marika Tortelier from IRD (author of the map), and thank the translators and referees for their constructive comments. 


\section{References}

Ardilly P., 1994, Les techniques de sondage. Ed. Technip, Paris.

Aubanel A., 1993, Valeur socio-économique du milieu corallien récifal et de ses ressources. Application à une île océanique du Pacifique sud : Moorea, archipel de la Société. Thèse de Doctorat, Université Michel de Montaigne, Bordeaux.

Botsford W., Castilla J.C., Peterson C.H., 1997, The management of fisheries and marine ecosystems. Science 277, 509-514.

Cochran W.G., 1963, Sampling techniques, 2nd Edition. Wiley, New York.

Dale V.H., Beyeler S.C., 2001, Challenges in the development and use of ecological indicators. Ecol. Indicators 1, 3-10.

Dalzell P., Adams T.J.H., Polunin N.V.C., 1996, Coastal fisheries in the Pacific islands. In: Ansell A.D., Gibson R.N. (Eds.), Oceanography and marine biology: an annual review 34, pp. 395531.

Escofier B., Pagès J., 1988, Analyses factorielles simples et multiples. Objectifs, méthodes et interprétations. Bordas, Paris.

Garcia S.M., Staples J.M., 2001, Sustainability reference systems and indicators for responsible marine capture fisheries: A review of concepts and elements for a set of guidelines. Mar. Freshwater Res. 51, 385-426.

Grosbras J.-M., 1987, Méthodes statistiques des sondages. Economica, Paris.

INSEE-ITSEE, 1997, Images de la population de la NouvelleCalédonie. Principaux résultats du recensement de 1996. Institut national de la statistique et des études économiques, Paris, INSEE Résultats n ${ }^{\circ}$ 523, Démographie Société 55.

ITSEE, 1993a, Budget Consommation des Ménages 1991. Principaux résultats (tableaux). Public. Institut territorial de la statistique et des études économiques, Nouméa, 1.

ITSEE, 1993b, Budget Consommation des Ménages 1991. Ressources des ménages (analyse). Public. Institut territorial de la statistique et des études économiques, Nouméa, 3.

ITSEE, 1993c, Rapport sur la méthodologie et l'organisation de l'enquête "Budget Consommation des Ménages 1991 ”. Public. Institut territorial de la statistique et des études économiques, Nouméa.

ITSEE, 1993d, Recensement général agricole 1991 en NouvelleCalédonie. Public. Institut territorial de la statistique et des études économiques, Nouméa, 2.

ITSEE, 1998, Panorama des tribus. Province des îles Loyauté, Nouvelle-Calédonie. Institut territorial de la statistique et des études économiques, Nouméa.

Kulbicki M., 1995, Le potentiel halieutique de l'atoll d'Ouvea : condensé des travaux réalisés par l'ORSTOM de 1991 à 1994.
In: Dalzell P. \& Adams T.J.H. (Eds), South Pacific Commission and forum fisheries agency workshop on the management of South Pacific inshore fisheries. South Pacific Commission, Nouméa, 2, 569-612.

Kulbicki M., Bargibant G., Menou J.-L., Mou Tham G., Thollot P., Wantiez L., Williams J., 1994, Évaluation des ressources en poissons du lagon d'Ouvea. $3^{\text {ème }}$ partie : les poissons. Rapp. Conv. Sci. Mer Biol. Mar. ORSTOM Nouméa, 11.

Kurtz J.C., Jackson L.E., Fisher W.S., 2001, Strategies for evaluating indicators based on guidelines from the Environmental Protection Agency's Office of Research and Development. Ecol. Indicators $1,49-60$.

Labrosse P., Letourneur Y., 1998, Définition et mise en œuvre de méthodes de suivi des stocks et de la pression de pêche des poissons d'intérêt commercial des lagons de la Province nord de la Nouvelle-Calédonie. Rapp. Conv. Sci. Mer Biol. Mar. ORSTOM Nouméa, 21.

Labrosse P., Letourneur Y., Kulbicki M., Paddon J., 2000, Fish stock assessment of the Northern New Caledonian logoons: Fishing pressure, potential yields and impact on management options. Aquat. Living Resour. 13(2), 91-98.

Labrosse P., Fichez R., Farman R., Adams T., 2000, New Caledonia. In: Sheppard C. (Ed.), Seas at the Millenium: An Environmental Evaluation. Elsevier Science, Vol. II, pp. 723-736.

Labrosse P., 2003, Structure et exploitation des peuplements de poissons récifaux commerciaux des lagons de la Province Nord de Nouvelle-Calédonie (Pacifique ouest). Thèse doctorale École Pratique des Hautes Études.

Lebart L., Morineau A., Lambert T., Pleuvret P., 1987, SPAD ${ }^{\circledR}$ Manuel de référence. CISIA, Saint-Mandé.

Lebart L, Morineau A., Piron M., 1995, Statistique exploratoire multidimensionnelle. Dunod, Paris.

Leblic I., 1993, Les Kanak face au développement. La voie étroite. Presses Universitaires de Grenoble, Grenoble.

Loubens, 1975, Quelques aspects de la pêche en Nouvelle-Calédonie. Nouméa: Nature Calédonienne 9, 27-30.

MacManus J.W., 1997, Tropical marine fisheries and the future of coral reefs: A brief review with emphasis on Southeast Asia. Coral Reefs 16, 121-127.

Paddon, 1997, Fishing pressure on demersal lagoon fish in the North Province of New Caledonia, South Pacific: Evaluation, impact on stock assesment and implications for management. Master of Arts Thesis, RSMAS, University of Miami.

Ward J.H., 1963, Hierarchical grouping to optimize and objective function. J. Am. Stat. Assoc. 58.

Watson R., Pauly D., 2001, Systematic distorsion in world fisheries catch trend. Nature 414, 534-536. 